\title{
Directors' Efficiency and Performance of Enterprises Listed on the Nigerian Stock Exchange: A Motivation Perspective
}

\author{
Oliver Oji \\ Department of Accountancy, Faculty of Business Administration, University of Nigeria Nsukka, Nigeria
}

Received November 22, 2021; Revised December 20, 2021; Accepted January 25, 2022

\section{Cite This Paper in the following Citation Styles}

(a): [1] Oliver Oji, "Directors' Efficiency and Performance of Enterprises Listed on the Nigerian Stock Exchange: A Motivation Perspective," Universal Journal of Accounting and Finance, Vol. 10, No. 1, pp. 317 - 326, 2022. DOI: 10.13189/ujaf.2022.100132.

(b): Oliver Oji (2022). Directors' Efficiency and Performance of Enterprises Listed on the Nigerian Stock Exchange: A Motivation Perspective. Universal Journal of Accounting and Finance, 10(1), 317 - $326 . \quad$ DOI: 10.13189/ujaf.2022.100132.

Copyright $\odot 2022$ by authors, all rights reserved. Authors agree that this article remains permanently open access under the terms of the Creative Commons Attribution License 4.0 International License

\begin{abstract}
Directors are a strategic factor of success in any enterprise, thus their motivation should form a fundamental aspect for efficient achievement of the overall objective and improve performance of an enterprise. This study examined the effect of directors' efficiency on the performance of enterprises listed on the Nigeria Stock Exchange (NSE). Therefore, the specific objectives of the study are to ascertain the effect of directors' efficiency factor (DEF) on return on capital employed (RoCE), Tobin's Q (TQ) and earnings per share (EPS). Hypotheses were formulated in alternate form as directors' efficiency factor has a significant effect on capital employed (RoCE), Tobin's Q (TQ) and earnings per share (EPS). In order to achieve the objectives stated above, the study adopted ex-post facto research design, and data were sourced from African Financials, Nigeria Stock Exchange (NSE) Fact Book and Annual Reports and Accounts of the enterprises under study. Eighty-eight enterprises were selected using purposive sampling technique from 2010 to 2019 , and data collected were analyzed using panel data regression model. The study found that DEF has a positive and significant effect on RoCE, but has a negative and significant effect on EPS and has an insignificant negative effect on TQ. Hence, the study recommended that regulatory agencies of the government should ensure that remuneration/compensation/pay package of Directors is commensurate with the performance indicators of the
\end{abstract}

enterprise; and fringe benefits for Directors should be structured as a means of motivation that could increase their efficiency. Stakeholders would continuously and critically review the activities of the Directors, analyze the growth rate as well as evaluate the performance indices of the enterprises in order to determine any form of augmentation.

Keywords Directors' Efficiency, Motivation; Enterprise Performance

\section{Introduction}

Motivation is a stimulating factor that induces or propels human behavioral pattern. It is a process which consists of extrinsic and intrinsic factors. Extrinsic factors are a host of external things an individual requires as an incentive to increase productivity. These include remuneration, bonuses, promotion and fringe benefits [35]. Intrinsic factors are internal to an individual, thus inherent and less tangible. More so, they are highly subjective as they represent the individual's perception and feelings which are highly unstable. These intrinsic motivational characteristics include healthy relationship, coordinated competence and progress [22]. Some schools of thought argue that extrinsic factors are more powerful and 
effective in attaining motivation, performance and commitment [5] in Legault ([21]), while other schools of thought argue that intrinsic factors are best suited for motivation [11] in Legault [21]. Researchers however, mostly consider a mixture of both intrinsic and extrinsic factors for greater efficiency. [25]. Nonetheless, there is no motivational factor as adequately effective as reward for outstanding performance which is an extrinsic factor. An individual who is properly rewarded for services rendered will definitely be motivated to exceed previous performance, all other things being equal. Hence, the medium in which individuals are motivated is through their sumptuous remuneration in consensus with the increase in the strategic performance and shareholders' value of an enterprise. In other to propel the motivational impulse of Directors, enterprises must meet the needs of the Directors through their remuneration or compensation. Therefore, enterprises must be efficiently managed by the Directors to enable the enterprises to meet their demands (remuneration). Truly, Directors deserve their remuneration but recent discoveries show that some of the enterprises over which they preside are going down or are being acquired by another company or insolvent [27] without downward review of Directors' remuneration. However, over the years, it has been observed that Directors' remuneration has been on the increase as opposed to the rate of increase in shareholder's value and strategic performance of the enterprise [15]. Although there might be ethical and competitive reasons for explaining the increase such as shortage of individuals who are considered to have the ability to lead major stock market enterprises. The implication is that Directors would only be concerned about what they have to gain, and this might affect the enterprise's sustainability and stability with regard to earnings. Conversely, if an emphasis on Directors' remuneration/compensation is structured toward motivating Directors, their efficiency would be enhanced. Thus, the improvement in enterprise performance will lead to the creation of strategic value for the enterprise without impairing sustainable growth in earnings.

There are many factors that affect the remuneration of directors, but the most profound one is the performance of the enterprise. The performance of an enterprise is ascertained based on certain parameters within a specified period of time. However, an enterprise can properly and adequately measure its performance using both internal and external approach. The internal performance approach is measured using accounting variables through the computation of financial ratios, while the external performance approach is measured using market variables through stock market performance.

Therefore, the main aim of this study is to examine Directors' efficiency in terms of being motivated to perform and the effect on the enterprise performance. The efficiency of Directors translates to the level of motivation driving them. The implication is that when Directors' motivation is low, their efficiency will be impaired; thus having resultant effect on enterprise performance and vice versa.

This study is framed into five (5) major themes which are: theme one deals with introduction and statement of the problem; theme two boarders on the review of relevant literature; theme three explains the method applied; theme four involves results and discussion of findings and lastly, theme five gives conclusion and recommendation.

\section{Review of Relevant Literature}

\section{Conceptual Review}

\section{Measurements of Performance}

Within the confines of this study, the measures of performance are return on capital employed, Tobin's Q and earnings per share. Return on capital employed is mathematically stated as earnings before interest and tax divided by capital employed. Earnings before interest and tax are the part of profit of an enterprise before deducting interest and tax. While capital employed arrived at by subtracting current liabilities from the total assets of an enterprise. Capital employed can be gotten from both the asset and the liability/equity sides of the statement of financial position [37]. According to Murtala, Ibrahim, Lawal and Abdullahi [26], capital employed measures or establishes the relationship between earnings and capital employed which portrays the efficient utilization of capital to generate revenue earnings for the enterprise. This, in essence, is an evaluation of financial result (earnings) against total financial resources put into use by the enterprise and makes return on capital employed ration as the utmost index to measure performance. This measure of performance assists enterprise's managers and investors to evaluate a business whether it produces more earnings or returns to settle its cost of capital. The implication is that the rate at which the enterprise is borrowing should be less when compared to the rate of return on the capital employed. However, the interpretation of the rate of return on capital employed should be done with caution. The return on capital employed can differ as a result of short-term impact and the composition of capital employed (gross capital employed, net capital employed and average capital employed) especially in carrying out comparative analysis with similar entities. Earnings per share is made up of basic earnings per share and diluted earnings per share. However, IAS 33 - Earnings per share has prescribed in detail as regards the computation, disclosure and presentation of the two components (basic and diluted) in the financial statements. For the purpose of this study, earnings per share is earnings after tax divided by the numbers of ordinary shares issued and fully paid. According to Wet [39], earnings per share is considered the most popular, the holy grail of financial performance 
index yet the most controversial. Despite earnings per share being widely used, Wet [39] revealed pertinent limitations in the interpretation and representation. For example, the failure of earnings per share to reflect shareholders' value creation, earnings management and inherent bias towards positive earnings per share growth. Therefore, in calculating earnings per share, enterprises should consider the significant impact of inflation on debts in its capital structure. Tobin's Q ratio is widely used in financial literatures as a proxy for performance. In managing the assets of an enterprise, Tobin's Q is used as an indicator that demonstrates performance especially to create value for the enterprise [17]. Tobin's $Q$ is one of the variables measuring the performance of an enterprise from the market or investment perspective. According to Rajeev, Liang and Mohinder [33], Tobin's Q is a ratio that is gotten by dividing the market value of an enterprise by the assets' replacement value which is used to investigate the diverse financial phenomenon and decisions. The Tobin's Q ratio is an indication of current and anticipated change in value and quality of an enterprise [20] which implies that the stock is undervalued or overvalued. Undervalued stock occurs when the replacement value of the asset of an enterprise is higher than the stock value, that is, Q is less than 1. While overvalued stock occurs when the replacement value of the asset of an enterprise is less than the stock value, that is, Q is higher than 1 .

\section{Directors' Motivation and Efficiency}

The term 'motivation' is believed to be an entity that compels one to action [14]. Several factors such as human resources, capital and environment influence the performance of an enterprise with human resource having the most impact. Hence, Directors control the resources and affairs of the enterprise through their monitoring responsibility. Thus, adequately motivated Directors are the pillars of successful enterprises [4]. Directors' efficiency is the relationship between benefits received by them and their efforts. This is better expressed as a ratio of Directors' input (benefit) and output (effort). The benefit or input of a Director could be represented by the remuneration/compensation/pay/fee which he receives for the services rendered. Furthermore, the effort or output of Directors could be represented by the revenue generated by the enterprise. Directors' efficiency is used because they are not the only human resource available to the enterprise, but they monitor and direct other resources. Therefore, unmotivated Directors may contribute less effort in their responsibilities and possibly be absent from place of work which will result in inefficiency. Implicitly, well-motivated Directors mean an efficient Director and increase in the performance of the enterprise. These motivated Directors would apparently need to motivate senior management staff if they want to achieve the strategic objectives of the enterprise. According to Mnzava [24] effectively motivated Directors result in achieving the strategic objectives of the enterprise and thus eliminating operational inefficiency. Improved motivation affects positively the achievement of strategic goals of an enterprise in general. Directors are strategic factors of success in any organisation, thus their motivation should form a fundamental aspect of achieving the overall enterprise objective.

\section{Directors' Remuneration and Performance}

Remuneration is the payment or compensation received for services rendered or employment which includes basic salary and any bonuses or other economic benefits that an employee or executive or Director receives during employment. Director remuneration can be described as a recompense given to a senior officer (executive and non-executive Directors) in correspondence with the policies set forth in the enterprise's articles of association as approved by the owners of the enterprise (shareholders). Hence, shareholders have the right to approve or disapprove the remuneration of Directors. The remuneration of Directors covers salary, bonuses, fees, commission, incentives and perquisite benefits such as health-care, use of enterprise properties which are usually tied to the performance (profit) of the enterprise [16], [28]. Directors' remuneration and performance have been and are still topical issues in both developed and developing countries. There are various factors that impinge on the performance of enterprises, and Directors' remuneration is one of such factors that impact on enterprise performance. According to Edvinsson and Joachim [13], remuneration includes all factors that contribute significantly towards Directors' motivation, their loyalty and eventually the performance of the enterprise. These factors are fixed or base pay (cash paid regardless of enterprise performance), qualification and wealth of experience of the Director as well as enterprise size. The relationship between enterprise expenses and performance has been established as a rise in enterprise expenses adversely affects the performance of the enterprise [28]. According to Shetty [36], Directors' remuneration is usually an analysis when analyzing the operation expenses of the enterprise for competitiveness. Compensation is a remuneration package which goes with labour services, and basic salary is a pivotal element of compensation with the assurance of minimum increment over time. 
Table 1. Empirical Review on Directors' Motivation

\begin{tabular}{|c|c|c|c|}
\hline AUTHOR(S) & OBJECTIVE(S) & METHODOLOGY & FINDING(S) \\
\hline $\begin{array}{l}\text { Walther, Moltner } \\
\text { and Morner } \\
\text { ([38]) }\end{array}$ & $\begin{array}{l}\text { To identify motivation profiles among } \\
\text { non-executive directors and explore } \\
\text { why they continue to serve on boards. }\end{array}$ & $\begin{array}{l}\text { Multiple case study } \\
\text { using within-case and } \\
\text { cross-case analysis. }\end{array}$ & $\begin{array}{l}\text { The study shows that non-executive director } \\
\text { motivation revolves around managerial incentives, } \\
\text { reputation, meaningfulness, congruence with firm } \\
\text { goals, and enjoyment. }\end{array}$ \\
\hline $\begin{array}{l}\text { Deci, Olafsen and } \\
\text { Ryan ([12]) }\end{array}$ & $\begin{array}{l}\text { To examine the relations of } \\
\text { self-determination theory to } \\
\text { transformational leader, job } \\
\text { characteristics, justice, compensation } \\
\text { and high quality performance in } \\
\text { workplace. }\end{array}$ & $\begin{array}{l}\text { Meta-analysis and } \\
\text { critiques. }\end{array}$ & $\begin{array}{l}\text { The study established that compensation systems } \\
\text { that reward people without pressuring them can add } \\
\text { to basic need supports. }\end{array}$ \\
\hline $\begin{array}{l}\text { Chareonwongask } \\
\text { ([9]) }\end{array}$ & $\begin{array}{c}\text { To examine the motivation of } \\
\text { cooperative boards of directors on the } \\
\text { effect of cooperative performance in } \\
\text { Thailand. }\end{array}$ & $\begin{array}{l}\text { This study used the } \\
\text { structural equation } \\
\text { modelling (SEM). }\end{array}$ & $\begin{array}{l}\text { The result suggests that the motivation of } \\
\text { cooperative board of directors significantly affects } \\
\text { cooperative performance. }\end{array}$ \\
\hline $\begin{array}{r}\text { Ogbeide and } \\
\text { Akanji ([28]). }\end{array}$ & $\begin{array}{l}\text { To evaluate the effect of executive } \\
\text { remuneration and firm's financial } \\
\text { performance in Nigeria. }\end{array}$ & $\begin{array}{l}\text { Panel estimate } \\
\text { generalised least } \\
\text { square (EGLS) with } \\
\text { fixed effect. }\end{array}$ & $\begin{array}{l}\text { Executive remuneration has a relationship with } \\
\text { firms' performance but negatively impacted on it } \\
\text { even though was not statistically significant. }\end{array}$ \\
\hline $\begin{array}{l}\text { Ryan and Deci } \\
\text { ([34]) }\end{array}$ & $\begin{array}{l}\text { To specify the conditions that tend to } \\
\text { support natural activity and } \\
\text { performance as against elicit or exploit } \\
\text { their vulnerability. }\end{array}$ & $\begin{array}{l}\text { This study used causal } \\
\text { research to evaluate } \\
\text { effect of } \\
\text { self-determination } \\
\text { theory in the work } \\
\text { place. }\end{array}$ & $\begin{array}{l}\text { The study found out that autonomy, competence } \\
\text { and relatedness foster greater internalisation and } \\
\text { integration, which is of great significance for } \\
\text { individuals who intend to motivate others in a way } \\
\text { that engenders commitment, effort and high-quality } \\
\text { performance. }\end{array}$ \\
\hline $\begin{array}{c}\text { Boivie, Graffin } \\
\text { and Pollock ([7]) }\end{array}$ & $\begin{array}{l}\text { To provide an unanswered questions in } \\
\text { corporate governance research on why } \\
\text { do directors serve on boards? }\end{array}$ & $\begin{array}{l}\text { The study used time } \\
\text { series logistic } \\
\text { regression with random } \\
\text { effects, Hausman test } \\
\text { and generalised } \\
\text { estimating equations } \\
\text { (GEE). }\end{array}$ & $\begin{array}{l}\text { The study established that the prestige associated } \\
\text { with being a director, the ability to have influence, } \\
\text { and identification with the director role make } \\
\text { directors less likely to exit. It was also discovered } \\
\text { that the value of being on the board of a prestigious } \\
\text { firm diminishes when the firm experience events } \\
\text { that tarnish its prestige, although these events } \\
\text { decrease the likelihood of director exit when } \\
\text { prestige is lacking. }\end{array}$ \\
\hline $\begin{array}{l}\text { De Jong, } \\
\text { Hooghiemstraand } \\
\text { Van Rinsum } \\
\text { ([10]) }\end{array}$ & $\begin{array}{l}\text { To explore the personal motives for } \\
\text { people to accept or turn down offers to } \\
\text { become a non-executive director. }\end{array}$ & $\begin{array}{l}\text { The study used partial } \\
\text { least square (PLS) } \\
\text { which is a form of } \\
\text { structural equation } \\
\text { modelling that is } \\
\text { particularly useful for } \\
\text { small companies. }\end{array}$ & $\begin{array}{l}\text { The study found out that bot intrinsic and extrinsic } \\
\text { motives are reasons for accepting and rejecting } \\
\text { offers. The study identified quality of management } \\
\text { and supervision as motives of accepting an offer } \\
\text { and reputational concern as a motive for rejection of } \\
\text { offers. }\end{array}$ \\
\hline $\begin{array}{l}\text { Akewushola and } \\
\text { Saka ([2]) }\end{array}$ & $\begin{array}{l}\text { To examine financial performance as a } \\
\text { determinant of executive } \\
\text { compensation. }\end{array}$ & $\begin{array}{l}\text { The study used panel } \\
\text { data regression model. }\end{array}$ & $\begin{array}{l}\text { The research findings revealed that financial } \\
\text { performance measured by profit after tax, capital } \\
\text { employed, return on equity and return on } \\
\text { investment, have significant influence on what is to } \\
\text { be paid as executive compensation. }\end{array}$ \\
\hline Olaniyan ([30]) & $\begin{array}{l}\text { To determine the effect of executive } \\
\text { compensation on the performance of } \\
\text { non-financial entities in the Nigerian } \\
\text { Stock Exchange (1996-2012) }\end{array}$ & $\begin{array}{l}\text { The study adopted } \\
\text { fixed effect regression } \\
\text { model. }\end{array}$ & $\begin{array}{l}\text { The study found that the measures of performance } \\
\text { (return on asset, return on equity and Tobin's Q) } \\
\text { reveal a negative significant relationship between } \\
\text { executive compensation. }\end{array}$ \\
\hline $\begin{array}{c}\text { Olalekan and } \\
\text { Bodunde ([29]) }\end{array}$ & $\begin{array}{l}\text { To investigate the impact of managing } \\
\text { Directors pay on performance of } 11 \\
\text { selected Nigerian quoted banks } \\
\text { between } 2005 \text { and } 2012\end{array}$ & $\begin{array}{l}\text { The study used } \\
\text { dynamic Generalized } \\
\text { Method of Moments } \\
\text { (GMM). }\end{array}$ & $\begin{array}{l}\text { The research reveals that managing Directors pay } \\
\text { exerts significant but negative influence on bank } \\
\text { performance measured by earnings per share in } \\
\text { Nigeria. }\end{array}$ \\
\hline $\begin{array}{l}\text { Oyerogba, Riro } \\
\text { and Memba } \\
\text { ([32]) }\end{array}$ & $\begin{array}{l}\text { To assess the impact of executive } \\
\text { compensation on firms' profitability on } \\
\text { listed entities in Nigeria using a period } \\
\text { of ten years ranging from } 2004 \text { to } 2013 \text {. }\end{array}$ & & $\begin{array}{l}\text { The results revealed that a significant positive } \\
\text { relationship exists between the Directors' cash } \\
\text { incentives, bonus issue of share and earnings per } \\
\text { share. The relationship between non-cash incentive } \\
\text { and earnings per share was insignificant. }\end{array}$ \\
\hline
\end{tabular}

Source: Authors Computation (2021)

According to Akewushola and Saka ([2]), factors of compensation structure are qualification, attitude, experience and existing rates in the competitive industry.
They stated that the type of employees who receive compensation/remuneration packages include company presidents, vice presidents, managing Directors, chief 
executive officers, chief financial officers and other senior executives. Junaidu and Sani [18] gave an elaborate definition of compensation. They defined compensation or pay as financial and non-financial benefits or rewards from an enterprise for services rendered. Also, Abdul, Muhammad, Ghazanfar and Muhammad [1] define compensation as financial payments and non-monetary rewards given to strategic level management for their services on behalf of the enterprise. The various types of compensation received by executive Directors include basic salary, stock options, bonuses, pension, severance package and grant of shares [6]. According to Akewushola and Saka [2], enterprise size, risk, age, and job are contending factors identified as determinants of Directors' remuneration. However, it has been observed that the size of the enterprise is one of the strong components that can influence Directors' remuneration/compensation [3].

According to Miyienda, Oirere and Miyogo [23], the nexus between enterprise performance and the remuneration of Directors can be viewed in two sides. Firstly, it could be viewed on the decision to base Directors' remuneration/compensation on enterprise performance. Secondly, it could be viewed on the residual effect of compensation/remuneration packages on enterprise performance. Implying that in other to motivate Directors, their remuneration/compensation should be based on performance of the enterprise. Therefore, it is obvious that Directors' remuneration/compensation and performance determine each other. Also, it is important to justify the remuneration/compensation received by Directors through proper evaluation of enterprise performance.

\section{Research Method}

This study adopted ex-post facto research design and data were sourced from African Financials, Nigeria Stock Exchange (NSE) Fact Book and Annual Reports and Accounts of enterprises under study listed on the Nigerian Stock Exchange from 2010 to 2019. The population of the study was 162 enterprises listed on the Nigerian Stock Exchange (NSE) during the period under study. However, after applying judgmental sampling technique, data of 88 enterprises was extracted. The criteria used for deselecting enterprises were unaudited and abridged financial statements of entities, unlisted entities on the Nigerian Stock Exchange (NSE) prior 2010 and enterprises' financial statements presented in foreign currency for the period under study.

\section{Model Specification}

To determine the effect of Directors' efficiency and the proxies of enterprise performance under study, this study adopted the panel regression model of either the random or fixed effect. Directors' efficiency is the independent variable proxies by Directors' efficiency factor (DEF) while the dependent variable is the performance proxies by return on capital employed (ROCE), Tobin's Q (TQ) and earnings per share (EPS). To control for the independent variable, log of net income (LNI) and log of net asset (LNA) were used as control variables. Descriptive statistical approach with the aid of tables, as well as panel data analysis were employed in testing the hypotheses and the unit root test was used to avoid spurious results.

This research used the panel data model to simulate the multi-variable regression to examine the effect between the dependent and independent variables. It is stated mathematically thus;

$$
\mathrm{Y}=\mathrm{f}(\mathrm{X})
$$

Where $\mathrm{Y}$ is the dependent variable and $\mathrm{X}$ is the independent variable.

This can be re-written as;

$$
\mathrm{PF}=\mathrm{f}(\mathrm{DEF})
$$

Where $\mathrm{PF}=$ Performance

$\mathrm{DEF}=$ Director's Efficiency Factor.

The above function can be stated statistically in a linear model;

$$
P F=\beta 0+\beta_{1} x_{i-t}+\beta_{2} x_{i-t}+\beta_{3} x_{i-t}+\mu
$$

Where PF is the dependent variable and $X_{i-t}, X_{i-t}, X_{i-t}$ are the independent variables. This can be re-written as:

$$
\mathrm{PF}_{\mathrm{i}-\mathrm{t}}=\mathrm{f}\left(\mathrm{DEF}_{\mathrm{i}-\mathrm{t}}, \mathrm{LNI}_{\mathrm{i}-\mathrm{t}}, \mathrm{LNA}_{\mathrm{i}-\mathrm{t}}\right)
$$

In the light of the above, the models below were estimated for hypotheses one to three using six sets of data (Directors' efficiency factor, return on capital employed, Tobin's Q, earnings per share, log of net income and log of net asset.). Each model will represent a given hypothesis respectively.

Starting with our first hypothesis which says: Directors' efficiency factor has significant effect on return on capital employed is represented as:

$$
\begin{aligned}
\operatorname{ROCE}_{\mathrm{i}-\mathrm{t}}= & \beta_{0}+\beta 1 \mathrm{DEF}_{\mathrm{i}-\mathrm{t}}+\beta 2 \mathrm{LNI}_{\mathrm{i}-\mathrm{t}}+ \\
& +\beta 3 \mathrm{LNA}_{\mathrm{i}-\mathrm{t}}+\mu
\end{aligned}
$$

For hypothesis two which states that Directors' efficiency factor has significant effect on Tobin's Q is represented as:

$$
\mathrm{TQ}_{\mathrm{i}-\mathrm{t}}=\beta_{0}+\beta 1 \mathrm{DEF}_{\mathrm{i}-\mathrm{t}}+\beta 2 \mathrm{LNI}_{\mathrm{i}-\mathrm{t}+} \beta 3 \mathrm{LNA1}_{\mathrm{i}-\mathrm{t}}+\mu
$$

For hypothesis three which states that Directors' efficiency factor has significant effect on earnings per share is represented as:

$$
\mathrm{EPS}_{\mathrm{i}-\mathrm{t}}=\beta_{0}+\beta 1 \mathrm{DEF}_{\mathrm{i}-\mathrm{t}}+\beta 2 \mathrm{LNI}_{\mathrm{i}-\mathrm{t}+} \beta 3 \mathrm{LNA} 1_{\mathrm{i}-\mathrm{t}}+\mu
$$

Where:

$\mathrm{DEF}=$ Directors' efficiency factor; ROCE $=$ Return on capital employed; TQ = Tobins Q; EPS = Earnings per share; LNI $=\log$ of Net Income; LNA1 $=\log$ of Net Asset; $\beta_{0}=$ Constant indicating the point of interception; $\beta_{1}=$ Coefficient of explanatory Variable and $\mu=$ Error term. 


\section{Decision Rule}

If the P-values as presented above are less than $5 \%$, the null hypothesis is rejected and the alternative hypothesis accepted. On the other hand, if the P-value does not have a positive sign and its probability greater than 0.05 , the null hypothesis is accepted and the alternate rejected.

\section{Results and Discussion of Findings}

The result shows the spread and variation in Director's efficiency factor at 0.158611 , return on capital employed at 0.237490 , return on asset 0.089123 , return on equity at 0.370181 , Tobins Q at 13.14249, earning per share at 2.162506 while the control variables, net income stood at
7.416463 and net asset at 9.359819. All variables except the control variables show a positive skewness of $23.63765,9.792531,3.726003,26.93747,29.35400$ and 5.743177 respectively measuring the degree of departure from the mean. On the other hand, net income and net asset show a negative skewness of -1.621005 and -0.279063 respectively. All variables show a positive value for kurtosis. These revealed that the degree of tailedness of all variables used within the period has a heavier tail and this is called leptokurtic distribution.

The correlation matrix for the dependent and independent variables is demonstrated in table 3 . The coefficients between all variables are found to be significant at 0.01 level of significance. In addition, it is showed that all the variables are not highly correlated with each other.

Table 2. Descriptive statistics of variables for the period, 2010-2019

\begin{tabular}{|c|c|c|c|c|c|c|}
\hline & DEF & ROCE & TQ & EPS & LNI & LNA1 \\
\hline Mean & 0.158611 & 0.237490 & 13.14249 & 2.162506 & 7.416463 & 9.359819 \\
\hline Median & 0.029550 & 0.126500 & 0.058350 & 0.540000 & 7.588577 & 9.123582 \\
\hline Maximum & 44.43640 & 8.826700 & 10554.00 & 57.63000 & 12.61422 & 13.80203 \\
\hline Std. Dev. & 1.662407 & 0.540935 & 356.8402 & 4.797516 & 2.764511 & 1.898723 \\
\hline Skewness & 23.63765 & 9.792531 & 29.35400 & 5.743177 & -1.621005 & -0.279063 \\
\hline Kurtosis & 599.1090 & 126.7993 & 867.2200 & 49.96961 & 8.214020 & 4.723549 \\
\hline Jarque-Bera & 13111301 & 576027.3 & 27511840 & 85729.61 & 1379.068 & 120.3446 \\
\hline Observations & 880 & 880 & 880 & 880 & 880 & 880 \\
\hline
\end{tabular}

Source: E-view 10.0 Output, 2021

Table 3. Correlation Analysis

\begin{tabular}{|c|c|c|c|c|c|c|}
\hline & DEF & ROCE & TQ & EPS & LNI & LNA1 \\
\hline DEF & 1.0000 & & & & & \\
\hline ROCE & -0.025596 & 1.0000 & & & & \\
\hline TQ & -0.003413 & -0.015442 & 1.0000 & & & \\
\hline EPS & -0.031864 & 0.097235 & -0.015677 & 1.0000 & & \\
\hline LNI & -0.154873 & 0.028411 & -0.120810 & 0.171789 & 1.0000 & \\
\hline LNA1 & -0.029664 & -0.198915 & -0.189981 & 0.204998 & 0.619485 & 1.0000 \\
\hline
\end{tabular}

Source: E-view 10.0 Output, 2021

Table 4. Summary of Panel Unit Root Test

\begin{tabular}{|c|c|c|c|c|c|}
\hline Variables & Levin, Lin \& Chu $t$ & $\begin{array}{c}\text { Im, Pesaran and Shin } \\
\text { W-stat }\end{array}$ & $\begin{array}{l}\text { ADF - Fisher } \\
\text { Chi-square }\end{array}$ & $\begin{array}{l}\text { PP - Fisher } \\
\text { Chi-square }\end{array}$ & Status \\
\hline \multirow[t]{2}{*}{ DEF } & $-39.9579 * * *$ & $-8.93210 * * *$ & $343.933 * * *$ & $354.325 * * *$ & \\
\hline & $(0.0000)$ & $(0.0000)$ & $(0.0000)$ & $(0.0000)$ & $1(0)$ \\
\hline \multirow[t]{2}{*}{ ROCE } & $-51.8098 * * *$ & $-12.1623 * * *$ & $406.879 * * *$ & $555.908 * * *$ & \\
\hline & $(0.0000)$ & $(0.0000)$ & $(0.0000)$ & $(0.0000)$ & $1(0)$ \\
\hline \multirow[t]{2}{*}{ TQ } & $331.537 * *$ & $-50.5468 * * *$ & $305.870 * * *$ & $494.297 * * *$ & \\
\hline & $(0.0000)$ & $(0.0000)$ & $(0.0000)$ & $(0.0000)$ & $1(1)$ \\
\hline \multirow[t]{2}{*}{ EPS } & $-90.0042 * * *$ & $-12.8380 * * *$ & $317.232 * * *$ & $433.898 * * *$ & \\
\hline & $(0.0000)$ & $(0.0000)$ & $(0.0000)$ & $(0.0000)$ & $1(0)$ \\
\hline \multirow[t]{2}{*}{ LNI } & $-22.1701 * * *$ & $-8.74643 * * *$ & $409.456 * * *$ & $724.004 * * *$ & \\
\hline & $(0.0000)$ & $(0.0000)$ & $(0.0000)$ & $(0.0000)$ & $1(1)$ \\
\hline \multirow[t]{2}{*}{ LNA1 } & $-23.6669 * * *$ & $-5.74701 * * *$ & $296.231 * * *$ & $358.115^{* * *}$ & \\
\hline & $(0.0000)$ & $(0.0065)$ & $(0.0011)$ & $(0.0000)$ & $1(0)$ \\
\hline
\end{tabular}

Source: E-view 10.0 Output, 2021 
The P-values are in parenthesis. They are all smaller than $1 \%$; so the null hypothesis is rejected, we therefore conclude that the variables series are stationary. The result illustrates that all the variables both explanatory, regressor and control variables are stationary at both levels and $1^{\text {st }}$ difference.

\section{Panel Regression Analysis}

Hypothesis One: Directors' efficiency factor has significant effect on return on capital employed

Haussmann Test Hypothesis

$\mathrm{H}_{\mathrm{o}}$ : Random effect model is appropriate

$\mathrm{H}_{1}$ : Fixed effect model is appropriate;

If the p-value of the test result as presented in table 5 below is less than 5\%, reject the null hypothesis otherwise accept the alternate hypothesis.

Table 5. Haussmann Test for Hypothesis One

\begin{tabular}{|c|c|c|c|}
\hline \multicolumn{4}{|c|}{ Hypothesis One } \\
\hline Test summary & $\begin{array}{c}\text { Chi-Sq. } \\
\text { Statistic }\end{array}$ & $\begin{array}{c}\text { Chi-Sq. } \\
\text { d.f. }\end{array}$ & Prob. \\
\hline $\begin{array}{c}\text { Cross-section } \\
\text { random }\end{array}$ & 0.960273 & 3 & 0.8109 \\
\hline
\end{tabular}

Source: E-view 10.0 Output, 2021

The Haussmann test was adopted so as to decide on the best fit model for the test. The cross-section chi-square statistic with 5 degree of freedom is 0.96 and the p-value is 0.811 as presented in table 5 above. The p-value of the Haussmann chi-square statistics is greater than $5 \%$ so the null hypothesis is accepted for hypothesis one. In conclusion, random effect model is a better option than the fixed effect for hypothesis one.

Table 6. Directors' efficiency factor has significant effect on return on capital employed

Dependent Variable: Return on Capital Employed

\begin{tabular}{|c|c|c|c|c|}
\hline Variables & Coefficient & Std Error & t-statistics & Pro. \\
\hline DEF & 0.004718 & 0.007038 & 0.670368 & 0.5028 \\
\hline LNI & 0.066131 & 0.031669 & 2.088210 & 0.0371 \\
\hline LNA01 & -0.127060 & 0.045967 & -2.764153 & 0.0058 \\
\hline $\mathrm{C}$ & 0.936268 & 0.257784 & 3.631983 & 0.0003 \\
\hline $\mathrm{R}^{2}$ & $8.6 \%$ & & & \\
\hline $\begin{array}{c}\text { Adjusted } \\
\text { R-square }\end{array}$ & 0.08 & & & \\
\hline F- stat & $27.32 \%$ & & & \\
\hline P-value & 0.000000 & & & \\
\hline $\begin{array}{c}\text { Durbin- } \\
\text { Watson } \\
\text { stat }\end{array}$ & $11.96 \approx 2$ & & & \\
\hline
\end{tabular}

Source: E-view 10.0 Output, 2021

From table 6 , the $\mathrm{R}^{2}$ of $8.6 \%$ represent the goodness of fit of the panel regression. The independent variable is responsible for $8.6 \%$ variation in the dependent variable with an unexplained variation of $91.4 \%$. This implies there are other variables that are responsible for change in the dependent variable which is not accounted for. Although this figure is high, it cannot discredit the model because the result shows that the data set are normally distributed as evidenced by the F-statistic of 27.32, Durbin-Watson stat of 1.96 approximately 2 and the corresponding probability value of 0.000000 . These parameters all showed a joint significant of the variables used. This implies the result is good enough for a meaningful analysis. Director's efficiency factor revealed a positive and significant effect on return on capital employed of the sampled enterprises in Nigeria for the period studied. This implies a unit increase in Director's efficiency factor correspondingly results to a unit increase in return on capital employed of the sampled enterprises. This finding is in line with the findings of Olayinka [31] whose finding revealed a positive and significant impact of board structure on corporate financial performance.

Hypothesis Two: Directors' efficiency factor has significant effect on Tobins $Q$

Table 7. Haussmann Test for Hypothesis Two

\begin{tabular}{|c|c|c|c|}
\hline \multicolumn{4}{|c|}{ Hypothesis Two } \\
\hline Test summary & $\begin{array}{c}\text { Chi-Sq. } \\
\text { Statistic }\end{array}$ & $\begin{array}{c}\text { Chi-Sq. } \\
\text { d.f. }\end{array}$ & Prob. \\
\hline $\begin{array}{c}\text { Cross-section } \\
\text { random }\end{array}$ & 6.309750 & 3 & 0.0975 \\
\hline
\end{tabular}

Source: E-view 10.0 Output, 2021

The cross-section chi-square statistic with 5 degree of freedom is 6.31 and the p-value is 0.09 as presented in table 7. The p-value of the Haussmann chi-square statistics is greater than $5 \%$, so the null hypothesis is accepted for hypothesis two. In conclusion, random effect model is a better option than the fixed effect for hypothesis two.

Table 8. Directors' efficiency factor has significant effect on Tobins Q Dependent Variable: Tobins Q

\begin{tabular}{|c|c|c|c|c|}
\hline Variables & Coefficient & Std Error & t-statistics & Pro. \\
\hline DEF & -1.521493 & 7.465238 & -0.203810 & 0.8386 \\
\hline LNI & -140.2769 & 16.57374 & -8.463804 & 0.0000 \\
\hline LNA01 & -16.38081 & 10.13406 & -1.616412 & 0.1064 \\
\hline C & 1448.348 & 152.2340 & 9.513963 & 0.0000 \\
\hline R $^{2}$ & $20 \%$ & & & \\
\hline $\begin{array}{c}\text { Adjusted } \\
\text { R-square }\end{array}$ & 0.11 & & & \\
\hline F- stat & $2.25 \%$ & & & \\
\hline P-value & 0.000000 & & & \\
\hline $\begin{array}{c}\text { Durbin-W } \\
\text { atson stat }\end{array}$ & 12.43 & & & \\
\hline
\end{tabular}

Source: E-view 10.0 Output, 2021

Table 8 shows the panel least square result for hypothesis two. From the result, the $\mathrm{R}^{2}$ of $20 \%$ represent the goodness of fit of the panel regression. The independent variable is responsible for $20 \%$ variation in 
the dependent variable with an unexplained variation of $80 \%$. This implies there are other variables that are responsible for change in the dependent variable which is not accounted for. Although this figure is high it cannot discredit the model because the result shows that the data set are normally distributed as evidenced by the F-statistic of 2.25, Durbin-Watson stat of 2.43 and the corresponding probability value of 0.000000 . These are pointers that the result is good enough for a meaningful analysis. Director's efficiency factor revealed a negative and insignificant effect on Tobin's Q of the sampled enterprises in Nigeria for the period studied. This implies a unit increase or decrease in Director's efficiency factor correspondingly would not result to a unit increase or decrease in Tobin $Q$ of the sampled enterprises. This finding is in line with the findings of Olaniyan [30] and Campbell [8] whose findings have a negative but significant relationship between executive compensation and the accounting based measure of performance used. Furthermore, the finding of Miyienda, Oirere and Miyogo [23] established statistically positive but weak effect between Tobin's Q and Directors' remuneration, which does not align with the result of this study.

Hypothesis Three: Directors' efficiency factor has significant effect on Earnings per Share

Table 9. Haussmann Test for Hypothesis Three

\begin{tabular}{|c|c|c|c|}
\hline \multicolumn{4}{|c|}{ Hypothesis Three } \\
\hline Test summary & Chi-Sq. Statistic & Chi-Sq. d.f. & Prob. \\
\hline $\begin{array}{c}\text { Cross-section } \\
\text { random }\end{array}$ & 0.711960 & 3 & 0.8704 \\
\hline
\end{tabular}

Source: E-view 10.0 Output, 2021

The cross-section chi-square statistic with 5 degree of freedom is 0.71 and the p-value is 0.87 as presented in table 9. The p-value of the Haussmann chi-square statistics is greater than $5 \%$, so the null hypothesis is accepted for hypothesis three. In conclusion, random effect model is a better option than the fixed effect for hypothesis three.

Table 10. Directors' efficiency factor has significant effect on Earnings per Share

Dependent Variable: Earnings per Share

\begin{tabular}{|c|c|c|c|c|}
\hline Variables & Coefficient & Std Error & t-statistics & Pro. \\
\hline DEF & -0.047241 & 0.023659 & -1.996739 & 0.0462 \\
\hline LNI & 0.119968 & 0.073897 & 1.623443 & 0.1049 \\
\hline LNA01 & 0.409239 & 0.049535 & 8.261666 & 0.0000 \\
\hline C & -2.546870 & 0.345135 & -7.379356 & 0.0000 \\
\hline $\mathrm{R}^{2}$ & $4.6 \%$ & & & \\
\hline $\begin{array}{c}\text { Adjusted } \\
\text { R-square }\end{array}$ & 0.04 & & & \\
\hline F- stat & $13.90 \%$ & & & \\
\hline P-value & 0.000000 & & & \\
\hline $\begin{array}{c}\text { Durbin-Wat } \\
\text { son stat }\end{array}$ & 11.57 & & & \\
\hline
\end{tabular}

Source: E-view 10.0 Output, 2021
Table 10 shows the panel least square result for hypothesis three. From the result, the $\mathrm{R}^{2}$ of $4.6 \%$ represent the goodness of fit of the panel regression. The independent variable is responsible for $4.6 \%$ variation in the dependent variable with an unexplained variation of $95.4 \%$. This implies there are other variables that are responsible for change in the dependent variable which is not accounted for. Although this figure is high, it cannot discredit the model because the result shows that the data set are normally distributed as evidenced by the F-statistic of 13.90, Durbin-Watson stat of 1.57 approximately 2 and the corresponding probability value of 0.000000 . These are pointers that the result is good enough for a meaningful analysis. Director's efficiency factor revealed a negative but significant effect on earnings per share of the sampled enterprises in Nigeria for the period studied. By implication, a unit increase in Director's efficiency factor has significant negative effect on earnings per share of the sampled enterprises. This finding is in line with the findings of Oyerogba, Riro and Memba [32], whose result revealed a significant positive effect on the one hand and an insignificant negative effect on the other hand between executive compensation and financial performance. However, the finding of this study is not consistent with Khalid and Rehman [19] which found positively significant impact of Directors' remuneration on earnings per share in a study carried out on 70 Pakistani corporate firms listed on Karachi Stock Exchange for the period of $2007-2011$.

\section{Conclusions and Recommendation}

The empirical findings provide different effects of Directors' efficiency on the performance indicators of enterprises listed on the Nigerian Stock Exchange. Directors' efficiency factor has a significant effect on return on capital employed and earnings per share but insignificant on Tobin's Q. This indicates that most corporate enterprises do not assess the Directors' efficiency to determine how remuneration and fringe benefits motivate Directors inputs. Therefore, it is recommended that regulatory agencies such as the Corporate Affairs Commission (CAC), Securities and Exchange Commission (SEC) of Nigeria should ensure that remuneration/compensation/pay package of Directors is commensurate with the performance indicators of the enterprise. This is to prevent or control persistent increase in the remuneration/compensation/pay package of Directors especially when the enterprise's performance indicators are nose diving. Financial and fringe benefits for Directors should not be perceived as the only motivational factors that could increase their efficiency. Psychological needs that trigger motivation such as autonomous motivation, wellness and relatedness could also be considered. Shareholders must critically review the activities of the Directors, analyze the growth rate as 
well as evaluate performance indices of the enterprise. This will serve as a guide in determining if Directors have been efficient in the affairs of the enterprise as to deserve any form of augmentation.

\section{REFERENCES}

[1] Abdul, H., Muhammad, R., Ghazanfar, A. \& Muhammad, A. "Impact of compensation on employee performance: empirical evidence from banking sector of Pakistan". International Journal of Business and Social Science, 5(2), $1-7,2014$. https://pdf4pro.com/amp/veiw/impact-of-com pensation-on-employee-performance-5a8225.html

[2] Akewushola, R. O. \& Saka, R. O. "Executive compensation and organisational financial performances: evidence from selected diversified firms in Nigeria", IOSR Journal of Business and Management, 20(3), 8 - 17, 2018. http://www.iosrjournals.org/iosr-jef/papers/Vol12-issue1/S er-3/F1201035058.pdf

[3] Al-Dhamari, R. A. \& Ismail, K. N. I. K. "An investigation into the effect of surplus free cash flow, corporate governance and firm size on earnings predictability". International Journal of Accounting and Information Management, 22(2), 103 - 117, 2014. DOI: 10.1108/IJAM-04-2013-0034

[4] Amabile, T. M. "Motivational synergy: toward new conceptualizations of intrinsic and extrinsic motivation in the workplace", Human Resource Management Review, 3(3), 185 - 201, 1993. DOI: 10.1016/1053-4822(93)90012 $-\mathrm{S}$

[5] Amabile, T. M., DeJong, W. \& Lepper, M. R. "Effects of external imposed deadlines on subsequent intrinsic motivation", Journal of Personality and Social Psychology, 34(1), 92, 1976. DOI: 10.1037//0022-3514.1.92

[6] Bebchuk, L. \& Fried, J. "Pay without performance: the unfulfilled promise of executive compensation". Cambridge MA: Harvard University press, 2004. http://www.law.havard.edu/faculty/bebchuk/pdfs/Performa nce-Part2.pdf

[7] Boivie, S., Graffin, S. D. \& Pollock, T. G. "Time for me to fly: predicting director exit at large firms", Academy of Management Journal, 55(6), 1334 - 1359, 2012. DOI: 10.5465/amj.2010.1083

[8] Campbell, S. K. "CEO and executive vice president compensation and company performance: An empirical study", The International Journal of Business and Management, 3(2), 20 - 25, 2015. http://www.internationa ljournalcorner.com/index.php/theijbm/article/view/127452

[9] Chareonwongask, K. "Enhancing board motivation for competitive performance of Thailand's cooperatives", Journal of Cooperative Organisation and Management, 5(1), 1 - 13, 2017. DOI: 10.1016/j.jcom.2017.01.001

[10] De Jong, A., Hooghimstra, R. \& Van Rinsum, M. "To accept or refuse an offer to join the board: Dutch evidence", Long Range Planning, 47(5), 262 - 276, 2014. DOI: $10.1016 / \mathrm{j} / \mathrm{lrp} .2012 .06 .001$
[11] Deci, E. L. "Effects of externally mediated rewards on intrinsic motivation". Journal of Personality and Social Psychology, 18(1), $105-115$, 1971. DOI: $10.1037 / 0030644$

[12] Deci, E. L., Olafsen, A. H, \& Ryan, R. M. "Self-determination theory in work organisations: The state of science", The Annual Review of Organisational Psychology and Organisational Behaviour, 4(1), 19 - 43, 2017. DOI: 10.1146/annurev-orgpsych-032516-113108

[13] Edvinsson, L. \& Joachim, H. "Intelligent remuneration in the knowledge economy for growth of intellectual capital". Journal of Human Resource Costing and Accounting, 9(2), 112 - 122, 2005. DOI: 10.1108/14013380510645388

[14] Forgas, J. P. Williams, K. D. \& Laham, S.M. "Social motivation: conscious and unconscious process", Cambridge university press, 2005. DOI: $10.1017 /$ CBO978 0511735066

[15] Gregg, P., Jewell, S. \& Tonks, I. "Executive Pay and Performance: Did Bankers' Bonuses Causethe Crisis?" International Review of Finance, 12(1), 89 - 122, 2012. DOI: $10.1111 / \mathrm{j} .1468-2443.2011 .01136 . x$

[16] Herdan, A. \& Szczepańska, K. "Directors Remuneration and Companies' Performance the Comparison of Listed Companies in Poland and UK", Foundations of Management, 3(2), 41 - 54, 2011. DOI: 10.2478/v10238-0 12-0041-8

[17] Hutabarat, E. M. \& Senjaya, V. F. Tobin's Q analysis as an indicator used in measuring and analyzing banking industry of companies listed in KOMPAS100 period 2010 - 2014. Prosiding Seminar Nasional INDOCOMPAC, 2(3), 464 - 469, 2016. https://www.semanticscholar.org/paper/T OBIN\%E2\%99S-Q-ANALYSIS-AS-AN-INDICATOR-U DES-IN-AND-OF-Hutabarat-Senjaya/e552256aefe81ca8e 89e78a21d9c03df8d703ddb

[18] Junaidu, M. K. \& Sani, K. S. "Executive compensation and financial performance of listed banks in Nigeria: an empirical analysis". Research Journal of Accounting, 2(3), 1 - 13, 2014. http://www.researchjournali.com/view.php?i $\mathrm{d}=907$

[19] Khalid, S. \& Rehman, M. U. "Impact of Directors' remuneration on financial performance of a firm", International Journal of Information, Business and Management, 6(1), 180 - 196, 2014. https://wwwresearchg ate.net/publication/293781837_Impact_of_Directors' Re muneration_on_Financial_Performance_of_a_Firm

[20] Lang, L. H. P.,Stulz, R. M. \& Walking, R. A. "Managerial performance, Tobin's Q and the gains from successful tender offers", Journal of Financial Economics, 24(1), 137 - 154, 1989. http//www.sciencedirect.com/science/article/ pii/0304-405X(89)90075-5

[21] Legault, L. "Self-Determination Theory". Encyclopedia of Personality and Individual Differences, 2416 - 2419, 2017. DOI: 10.1007/978-3-319-28099-8_1162-1

[22] Manion, J. "From management to leadership". San Francisco, Jossy Bass, 2005.

[23] Miyienda, B., Oirere, C. O. \& Miyogo, J. "The relationship between director remuneration and performance of firms listed on the Nairobi securities exchange", The International Journal of Social Sciences, 
15(1), 1 - 17, 2013. https://www.semanticscholar.org/pape r/1-THE-RELATIONSHIP-BETWEEN-DIRECTOR-RE MUNERATION-OF-Miyienda-Oirere/bc2e2272b1dbe4d5 $14 \mathrm{c} 153 \mathrm{e} 5 \mathrm{c} 44431989534 \mathrm{f} 100$

[24] Mnzava, B. "Directors' remuneration and its determinants: what do we know?" Business and Management Review, 2(4), 42 - 59, 2012. http://www.businessjournalz.org/bmr

[25] Moran, C. M., Diefendorff, J. M., Kim, T. Y. \& Liu, Z. Q. "A profile approach to self-determination theory motivation at work". Journal of Vocational Behaviour, 81(3), 354 - 363, 2012. DOI: 10.1016/j.jvb.2012.09.002

[26] Murtala, S., Ibrahim, M., Lawal, S. \& Abdullahi, D. B. "Capital structure and return on capital employed of construction companies in Nigeria". African Journal of Accounting, Auditing and Finance, 6(1), 1 - 20, 2018. DOI: 10.1504/AJAAF.2018.091125

[27] Odewale, W. R. \& Kamardin, H. 'Directors' remuneration disclosure and transparency in Nigeria and the influence of block share ownership". International Journal of Business and Social Research, 5(8), 65 - 78, 2015. DOI: 10.18533/ijbsr.v5i8.819

[28] Ogbeide, S. \& Akanji, B. "Executive Remuneration and the Financial Performance of Quoted Firms: The Nigerian Experience", Management and Economics Review, 1 (2), 229 - 242, 2016. http://mer.ase.ro/files/2016-2/14.pdf

[29] Olalekan, O. C., \& Bodunde, O. B. "Effect of CEO pay on bank performance in Nigeria: Evidence from a generalized method of moments", British of Economics, Management and Trade, 9(2), 1 - 12, 2015.https://www.researchgate.ne t/publication/282199344_Effect_of_CEO_Pay_on_Bank_ Performance_in_Nigeria_Evidence_from_a_Generalized_ Method_of_Moments

[30] Olaniyan, S. O. "Executive compensation and the performance of non-financial firms on Nigerian Stock Exchange", Journal of Research in National Development, 13(2), 1-7, 2015.

[31] Olayinka, M. U. "Impact of board structure on corporate financial performance in Nigeria", International Journal of Business and Management, 5(10), 155 - 166, 2010. DOI: 10.5539/ijbm.v5n10p155
[32] Oyerogba, E. O., Riro, G. K. \& Memba, F. "The Perceived Relationship between Executive Compensation Package and Profitability of Listed Companies in Nigeria", European Journal of Business, Economics and Accountancy, 4(3), 11 - 22, 2016. https://www.researchgat e.net/publication/352247765_THE_PERCEIVED_RELAT IONSHIP_BETWEEN_EXECUTIVE_COMPENSATION _PACKAGE_AND_PROFITABILITY_OF_LISTED_CO MPANIES_IN_NIGERIA

[33] Rajeev, S. Liang, F., \& Mohinder, P. "Tobin's Q ratio and firm performance", International Research Journal of Applied Finance, 7(4), 1 - 10, 2016. DOI: 10.0704/article-2

[34] Ryan, R. \& Deci, E. L. "Self-determination theory and the facilitation of intrinsic motivation, social development, and well-being", American Psychologist, 55(2), 68 - 78, 2000.https://selfdeterminationtheory.org/SDT/documents/2 000_RyanDeci_SDT.pdf

[35] Shanks, N. H. "Management and motivation: Introduction to healthcare management". Jones \& Bartlett learning, United States, 2007.

[36] Shetty, S. "Impact of firm performance, multi-national and innovation in MNCS". Eing a published dissertation submitted to H. Wayne Huizenga School of Business and Entrepreneurial Nova South-eastern University, 2013. https://www.amazon,com/ipmact-performance-multination ality-innivation-internationalization/dp/3659503568

[37] Sing, J. \& Yadav, P. "Return on capital employed - a tool for analysing profitability of companies" International Journal of Techno-Management Research, 1(1), 1 - 13, 2013. ISSN: 2321-3744

[38] Walther, A., Moltner, H. \& Morner, M. "Non-executive director's motivation to continue serving on boards", International Journal of Business in Society, 17(1), 64 76, 2016. DOI: 10.1108/CG-052016-0120

[39] Wet, J. "Earnings per share as a measure of financial performance; does it obscure more than it reveals?" Corporate Ownership and Control, 10(4), 265 - 275, 2013. DOI: $10.22495 /$ cocy $10 i 4 c 2$ art3 